$\mathrm{DE}$

M E D I C I N A

T R O P I C A L

$\mathrm{DE}$

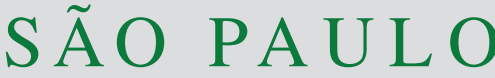

JOURNAL OF THE SÃO PAULO INSTITUTE OF TROPICAL MEDICINE

1Universidade de São Paulo, Faculdade de Medicina, Departamento de Patologia, São Paulo, São Paulo, Brazil

IInstituto de Assistência Médica ao Servidor Público Estadual, Programa de PósGraduação em Ciências da Saúde, São Paulo, São Paulo, Brazil

${ }^{3}$ Universidade Federal de Minas Gerais, Instituto de Ciências Biológicas, Departamento de Patologia Geral, Belo Horizonte, Minas Gerais, Brazil

${ }^{4}$ Universidade Federal do Pará, Núcleo de Medicina Tropical, Belém, Pará, Brazil

${ }^{5}$ Universidade do Estado do Pará, Centro de Ciências Biológicas e da Saúde, Belém, Pará, Brazil

'Universidade de São Paulo, Faculdade de Medicina, Hospital das Clínicas, Divisão de Clínica Dermatológica, São Paulo, São Paulo, Brazil

${ }^{7}$ Universidade de São Paulo, Instituto de Medicina Tropical de São Paulo, Laboratório de Dermatologia Tropical, São Paulo, São Paulo, Brazil

Correspondence to: Carla Pagliari Universidade de São Paulo, Faculdade de Medicina, Departamento de Patologia, Av. Dr. Arnaldo, 455, sala 1118, Cerqueira César, CEP 01246-903, São Paulo, SP, Brazil

Tel: +55 $113061-7238$.

E-mail: cpagliari@usp.br

Received: 23 April 2020

Accepted: 16 September 2020

\section{Lacaziosis: immunohistochemical evaluation of elements of the humoral response in cutaneous lesions}

\author{
Luciane Kanashiro-Galo', Ariane Fernandes Alexandre ${ }^{1,2}$, Wagner Luiz \\ Tafuri $^{3}$, Tânia Cristina Barboza ${ }^{1,2}$, Juarez Antonio Simões Quaresma ${ }^{4,5}$, \\ Arival Cardoso de Brito ${ }^{4}$, Gabriela Yasmin Francisca da Silva do \\ Nascimento ${ }^{1,2}$, Antonio Marques dos Santos Filho ${ }^{6}$, Mirian Nacagami Sotto ${ }^{1,7}$, \\ Carla Pagliari ${ }^{\circledR 1,2}$
}

\section{ABSTRACT}

Lacaziosis is a cutaneous mycosis caused by the fungus Lacazia loboi, described in different countries of Latin America and prevalent in the Amazon region. The ineffective immune response against the agent seems to be related to a Th2 pattern of cytokines. There are few reports exploring elements of the humoral response in these lesions. Our aim was to investigate some elements focusing on B cells, plasma cells and local expression of IgG and IgM antibodies. Forty skin biopsies of lower limbs were selected. The diagnosis of lacaziosis was based on direct mycological examination and histological analysis. The visualization of fungal cells was improved by using Gridley's staining. An immunohistochemical protocol was performed to detect the expression of B cells, plasma cells, IgG and IgM. A double staining was performed to explore the presence of yeasts in the cytoplasm of keratinocytes, using an anti-AE1 AE3 antibody over Gridley's staining. The inflammatory infiltrate consisted of macrophages, multinucleated giant cells, lymphocytes, and fibrosis. Fungal cells were frequent in the stratum corneum and in both, the dermis and, in $50 \%$ of the specimens, also in the epidermis. Cells expressing IgG were more abundant when compared to cells expressing $\operatorname{IgM}$. B cells and the presence of IgG might indicate that the humoral response promotes a Th2 immune response resulting in an anti-inflammatory phenotype. Our results lead us to suggest a possible role of B cells and immunoglobulins in the mechanisms of lacaziosis pathogenesis.

KEYWORDS: Lacaziosis. Humoral response. Skin. Human lesions. Immunohistochemistry.

\section{INTRODUCTION}

Lacaziosis is a cutaneous mycosis caused by the fungus Lacazia loboi, described in different countries of Latin America and prevalent in the Amazon region ${ }^{1}$. Lesions are frequently located on the arms, legs and ears and appear after a trauma caused by a sharp instrument or arthropod bites. Clinically, they are characterized as keloid, warty, nodular, ulcerated or plaque lesions. The local immune response has been explored, but some aspects of the immunopathogenesis are still poorly understood ${ }^{2,3}$.

Studies regarding the cellular immune response in lacaziosis lesions demonstrated the presence of macrophages and an intense expression of TGF- $\beta$, a fibrosis-associated cytokine, and the absence of well-organized granulomas ${ }^{4}$. The ineffective immune response against the agent seems to be related to a Th2-type cytokines pattern and the lesions comprise a clinical and immunological spectrum that varies from susceptible to resistant to treatment ${ }^{5}$. In addition, an expressive 
number of IL17-producing CD4+ T cells over TCD4+ Foxp3+ in lacaziosis skin lesions have been described, and it is suggested that the Th17 cytokine pattern may be present as an auxiliary mechanism for modulating the local immune response ${ }^{6}$. The cytotoxic function of CD8+ T cells was evidenced based on the detection of perforin and granzyme B and a role in the in situ immune response to eliminate the fungus was suggested. Similarly, by studying the cytotoxic cellular response in such lesions, we highlight and suggest an important role of these cytotoxic elements ${ }^{7}$.

Histologically, lacaziosis is already characterized by multifocal to coalescing dermal foci of granulomatous inflammation composed of macrophages, epithelioid cells, multinucleated giant cells, and often of large numbers of Gomori methanamine silver (GMS)-positive yeast cells, 6-12 $\mu \mathrm{m}$ in diameter, arranged individually or in chains and joined by tubular connections ${ }^{8}$. However, there are few reports exploring the presence of $\mathrm{B}$ cells, plasma cells and immunoglobulins in the lesions in situ. It is already known that patients with lacaziosis show increased serum IgG and IgM immunoglobulin levels ${ }^{9}$.

Our aim was to investigate some elements of the humoral immune response in such lesions focusing on the identification and quantification of CD20+ cells, plasma cells and local expression of IgG and IgM in the lesions.

\section{MATERIALS AND METHODS}

Forty skin biopsies of lower limbs from 40 lacaziosis patients were selected from the medical records of the Nucleo de Medicina Tropical, Universidade Federal do Para, Belem, PA, Brazil. The diagnosis was based on direct mycological examination and histological analysis. The visualization of fungal cells was improved by the Gridley's staining, based on the Schiff's reagent and aldehyde fuch $\sin ^{10}$. An immunohistochemical protocol was performed as described: following deparaffinization in xylene and hydration in ethanol, antigen recovery was performed in a TRIS/EDTA solution $\mathrm{pH} 9.0$ for $20 \mathrm{~min}$ at $95^{\circ} \mathrm{C}$. The primary antibodies anti-CD20 (Dako Cytomation, M755), anti-IgG (Dako Cytomation, A090), anti-IgM (Dako Cytomation, A091) and anti-plasma cells (CD138, Dako Cytomation, M7228) were applied at 1/400, 1/4000, 1/1000 and 1/500 dilutions, respectively. Following an overnight incubation at $4{ }^{\circ} \mathrm{C}$, the secondary antibodies and a streptavidin-biotin peroxidase complex was applied (LSAB, Dako, Carpinteria, CA, EUA), for $30 \mathrm{~min}$ each. Then, the 3,3-diaminobenzidine tetrahydroxychloride was used as the chromogen and the slides were counterstained with hematoxylin. We also performed a double immunohistochemistry to explore the presence of yeasts in the cytoplasm of keratinocytes, using an anti-AE1 AE3 antibody (Dako Cytomation, M3515) followed by the Gridley's staining.

All reactions were performed with positive and negative controls. The negative ones were composed of isotype controls and the omission of the primary antibody. Immunolabeled cells were quantified in nine randomized fields. Statistical analysis was performed using the GraphPad Prism version 5.0 program (GraphPad Software, Inc., San Diego, California, USA), using the Mann-Whitney test.

Biopsies were selected according to the representativeness of the sample; whose size was enough to perform all the immunohistochemical procedures.

This research was approved by the Ethics and Research Committee of Faculdade de Medicina, Universidade de Sao Paulo, process No 191/12.

\section{RESULTS}

The histological analyses of specimens showed epidermis with hyperplastic or ulcerated appearance. Fungal cells were frequently observed in the stratum corneum. The dermal changes were characterized by a clear band (grenz zone), of variable thickness separating the epidermis from the dermal infiltrate.

The inflammatory infiltrate consisted of macrophages, multinucleated giant cells, lymphocytes and fibrosis, visualized by hematoxylin-eosin staining. Fungal cells, visualized through the Gridley's staining, were observed in both, dermis and, in $50 \%$ of the specimens, also in epidermis, when the double staining was applied (Figure 1).

It was possible to observe immunolabeled cells with the anti-CD20, CD138, IgG and IgM in the inflammatory infiltrate of the lesions (Figure 2). The results on the quantification of positive cells were expressed as (median \pm SD) $12.44 \pm 82.24$ for CD20; $21.33 \pm 139.10$ for IgG; $3.55 \pm 18.97$ for IgM and $5.33 \pm 58.75$ for plasma cells (Figure 3).

\section{DISCUSSION}

Previous studies that characterized the inflammatory infiltrate in lacaziosis lesions evidenced the presence of both, plasma cells and B cells that allied to disorganized cells arrangements in the granuloma and the presence of many fungal cells, suggested that patients with lacaziosis present with immunoregulatory disturbances which are possibly responsible for the lack of containment of the pathogen ${ }^{11}$.

Our results seem to evidence that there is participation of the humoral immune response in cutaneous lacaziosis 


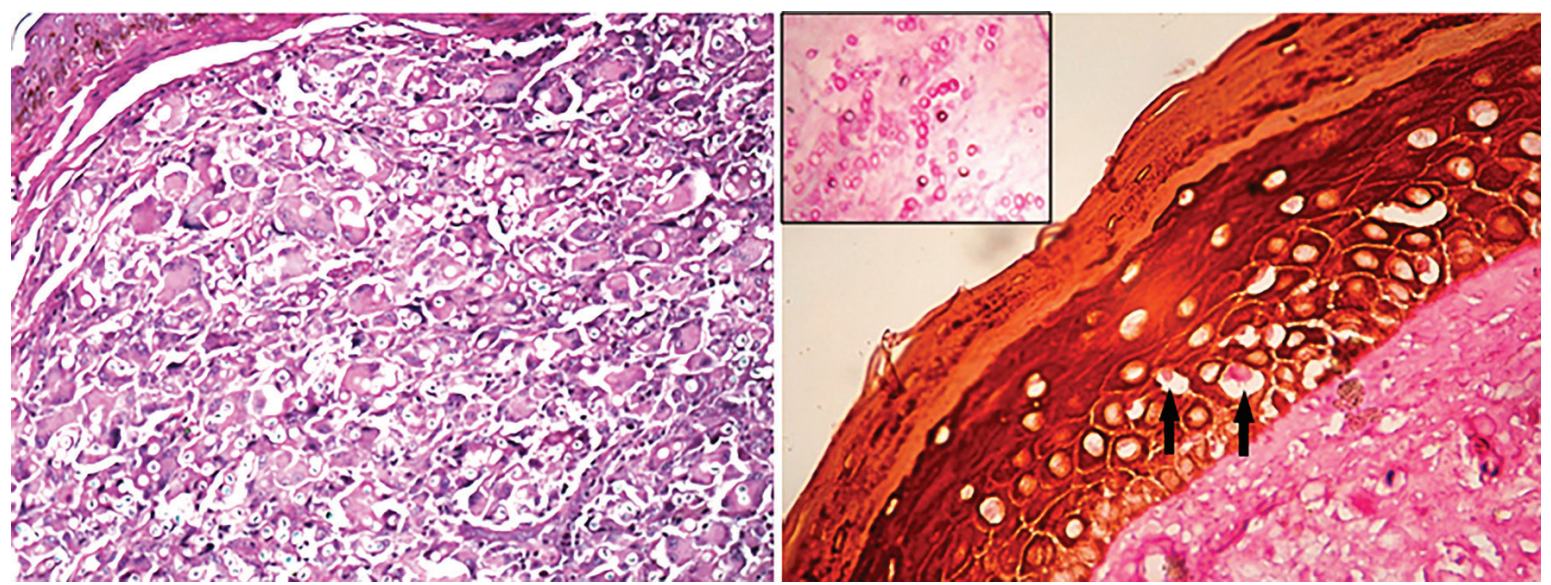

Figure 1 - Lacaziosis, skin lesions. A) Inflammatory infiltrate composed of macrophages, lymphocytes, epithelioid cells and multinucleated cells and a high number of fungal cells (Hematoxylin-Eosin, x 200); B) Double immunostaining evidencing the colocation of keratinocytes (in brown) and fungal cells (in purple) (x 400). Insert: single Gridley's staining evidencing fungal cells in the dermis (in purple).

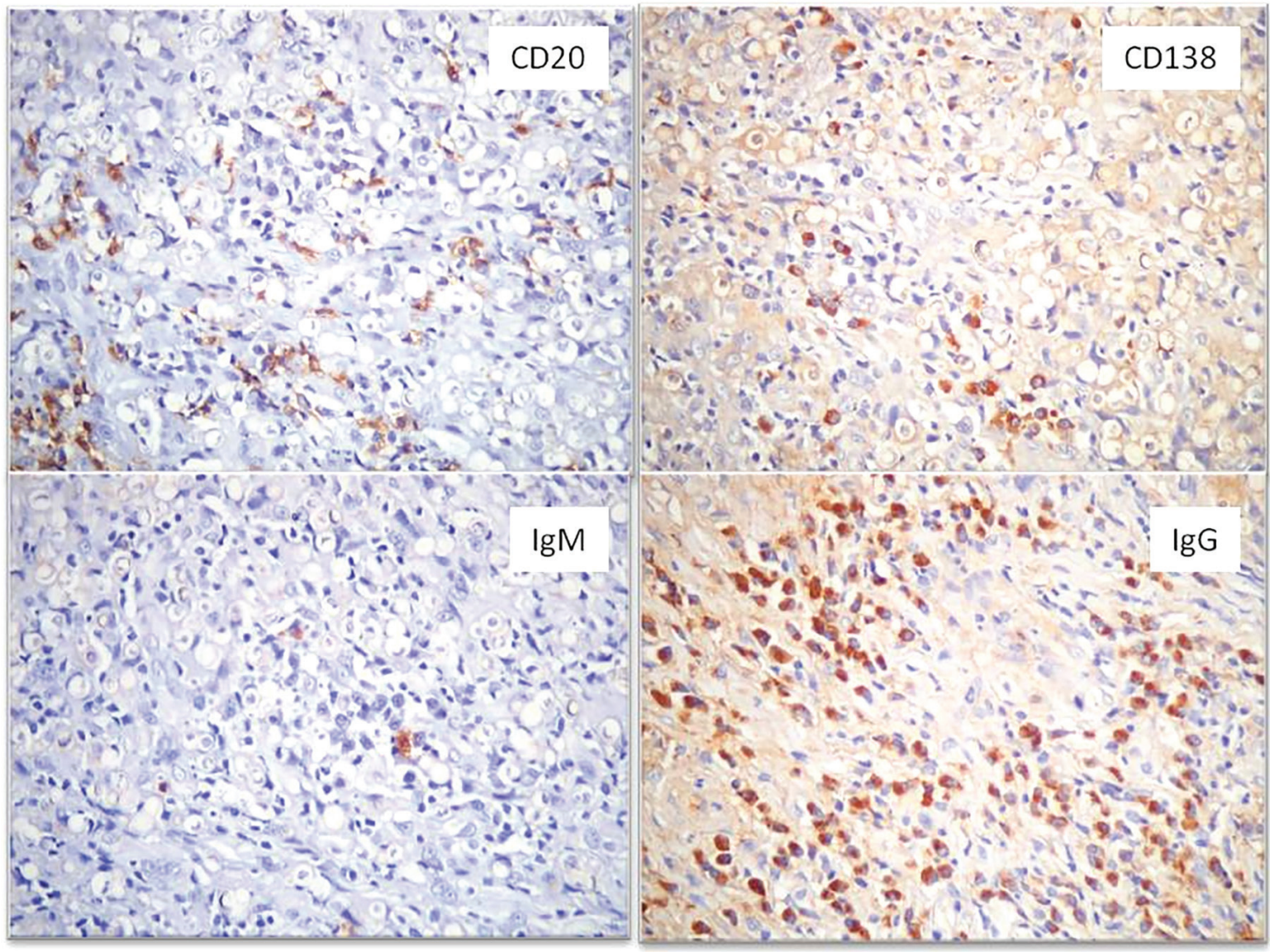

Figure 2 - Lacaziosis, skin lesions. Immunohistochemistry reaction visualized in brown. Upper left and right: High number of CD20+-B lymphocytes and CD138+-plasma cells in the inflammatory infiltrate, mixed with fungal cells in the granuloma; Lower left: Rare cells expressing IgM; Lower right: Intense expression of IgG in the inflammatory infiltrate (Streptavidin-Biotin HRP, x 200).

lesions. In fact, our immunohistochemistry results revealed the presence of many CD20-positive cells (B cells) and a high expression of IgG. In addition, this intense presence of both, CD20 and IgG positive cells was accompanied by other cells observed under routine microscopic analysis characterized as plasma cells, macrophages, epithelioid cells, and giant cells as well. Plasma cells are characterized as large cells with abundant cytoplasm and an eccentric nucleus with heterochromatin in a characteristic cartwheel. A predominance of $\operatorname{IgG}$ expression over $\operatorname{IgM}(\mathrm{p}<0.0001)$ 


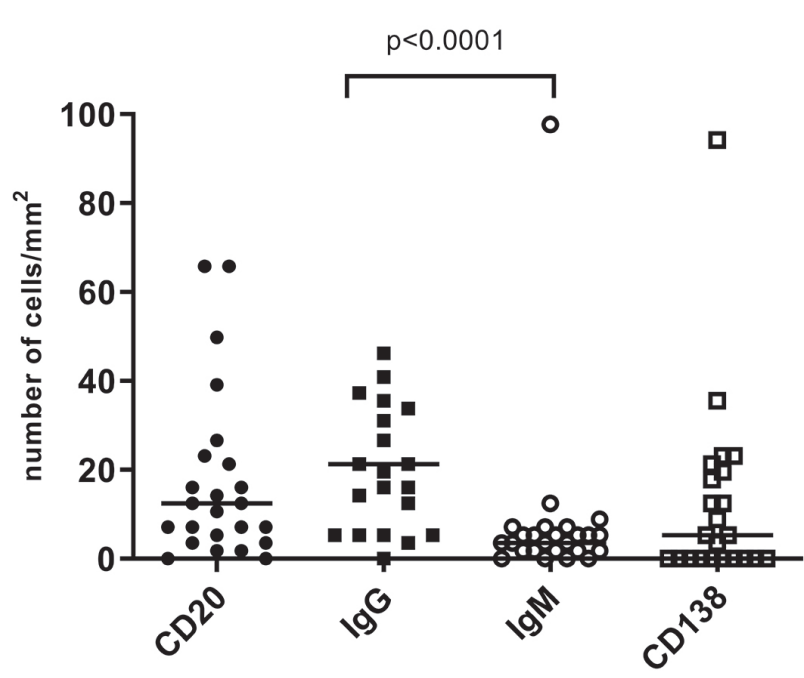

Figure 3 - Comparative analysis of immune-labeled cells expressing CD20, IgG, IgM and CD138. The comparison between cells expressing IgG and IgM evidenced a statistically significant difference $(p<0.0001)$. Values were expressed as the number of cells $/ \mathrm{mm}^{2}$. The median values \pm standard deviation were $12.44 \pm 82.24$ for CD20; $21.33 \pm 139.10$ for lgG; 3.5518 .97 for IgM and $5.33 \pm 58.75$ for plasma cells.

was also observed. Interestingly, previous studies showed normal levels of $\operatorname{IgG}, \operatorname{IgM}, \operatorname{IgA}$ and serum proteins in patients with lacaziosis ${ }^{12,13}$.

B cells with an immunoglobulin repertoire characterized mainly by IgG are results that might indicate that humoral response promotes a Th2 immune response and an antiinflammatory phenotype in infected macrophages. This idea is based on the role of B cells in infections diseases, especially those caused by intracellular parasites. For example, in experimental or human leishmaniasis, B cells appear to contribute to the persistence of parasites ${ }^{14-16}$. Miles et $a l .{ }^{15}$, in a murine model, demonstrated that parasite-specific immunoglobulins failed to protect mice and promoted the persistence of parasites in B cell-deficient mice. Christensen et al. ${ }^{17}$, in the American tegumentary leishmaniasis model, reported patients with increased parasite transcripts in tissues, which were related to higher levels of immunoglobulins in serum and tissues.

Th1 response is required for clearing these intracellular parasites. The Th1 response, allied to Th17 cytokines production were described in lacaziosis as providing antifungal protection and the absence of a local Th1 response, with low levels of IFN- $\gamma$, may result in fungal persistence ${ }^{18}$.

Previous observations suggested that antibodies bound to fungi may function as opsonins and facilitate the macrophage-mediated phagocytosis of the microorganism, in addition to complement activation. Moreover, fungi with morphological features of unviability were observed in the inflammatory infiltrate. It was previously described that lacaziosis is a disease of long evolution and lesions frequently present many fungal forms that are no longer viable $^{19,20}$. We did not perform viability tests in this study, however, as these authors ${ }^{19,20}$, we considered the unviability of the fungi in the studied lacaziosis lesions based on their morphological features.

Our results lead us to suggest a possible role of B cells and immunoglobulin $(\operatorname{IgG})$ in the mechanisms of lacaziosis pathogenesis. The observation in the present study of the predominance of cells expressing $\mathrm{IgG}$ might indicate that lacaziosis, as a chronic infectious disease, suffer a constant antigen stimulus, as previously considered. In frozen histological sections analyzed by immunofluorescence staining, deposits of $\mathrm{C} 3, \mathrm{IgG}$ and $\operatorname{IgM}$ were observed in the fungal wall of $100 \%, 91 \%$ and $18 \%$ of the lesions, respectively ${ }^{20}$.

Finally, we were also able to detect the presence of fungal cells in the keratinocytes by double immunohistochemistry using an anti-AE1 AE3 antibody and Gridley's staining, corroborating previous observations ${ }^{21}$.

\section{ACKNOWLEDGMENTS}

This work was supported by National Council for Scientific and Technological Development (CNPq), grant $\mathrm{N}^{\circ} 470512 / 2013-0$. AFA and GYFSN were supported by National Council for Scientific and Technological Development (scientific initiation scholarship). TCB was supported by a doctorate research fellowship of Coordenação de Aperfeiçoamento de Pessoal de Nível Superior (CAPES - Ministry of Education, Brazil). WLT is recipient of a post doctoral fellowship from the Research Scientific and Development Support Foundation of Sao Paulo (FAPESP)

\section{AUTHORS' CONTRIBUTIONS}

The authors' contributions were: substantial contributions to the conception or design of the work; or the acquisition, analysis, or interpretation of data for the work: AFA, GYFSN, AMSF, TCB, LKG, CP. Drafting the work or revising it critically for important intellectual content: WLT, JASQ, ACB, MNS, CP. Final approval of the version to be published: all. All authors read and approved the final manuscript. All authors made a substantial, direct and intellectual contribution to the work, and approved it for publication.

\section{CONFLICT OF INTERESTS}

The authors declare that they have no conflict of interests. 


\section{REFERENCES}

1. Silva D, Macedo C, Oliveira C, Unger D. Micose de Jorge Lobo simulando forma gomosa: um caso raro. An Bras Dermatol. 1996;71:211-3.

2. Talhari S, Talhari C. Lobomycosis. Clin Dermatol. 2012;30:420-4.

3. Paniz-Mondolfi A, Talhari C, Sander Hoffmann L, Connor DL, Talhari S, Bermudez-Villapol L, et al. Lobomycosis: an emerging disease in humans and delphinidae. Mycoses. 2012;55:298-309.

4. Xavier MB, Libonati RM, Unger D, Oliveira C, Corbett CE, Brito AC, et al. Macrophage and TGF-beta immunohistochemical expression in Jorge Lobo's disease. Human Pathol. 2008;39:269-74.

5. Quaresma JA, Unger D, Pagliari C, Sotto MN, Duarte MI, Brito AC. Immunohistochemical study of Langerhans cells in cutaneous lesions of the Jorge Lobo's disease. Acta Trop. 2010;114:59-62.

6. Kanashiro-Galo L, Pagliari C, Barboza TC, Brito AC, Xavier MB, Oliveira CM, et al. Th17 and regulatory T cells contribute to the in situ immune response in skin lesions of Jorge Lobo's disease. Med Mycol. 2016;54:23-8.

7. Alexandre AF, Quaresma JA, Barboza TC, Brito AC, Xavier MB, Oliveira CM, et al. The cytotoxic $\mathrm{T}$ cells may contribute to the in situ immune response in Jorge Lobo's Disease human lesions. Med Mycol. 2017;55:145-9.

8. Bossart GD, Romano TA, Peden-Adams MM, Schaefer AM, Rice $\mathrm{CD}$, Fair PA, et al. Comparative innate and adaptive immune responses in Atlantic Bottlenose dolphins (Tursiops truncatus) with viral, bacterial, and fungal infections. Front Immunol. 2019;10:1125.

9. Vilani-Moreno FR, Belone AF, Lara VS, Venturini J, Lauris JR, Soares CT. Detection of cytokines and nitric oxide synthase in skin lesions of Jorge Lobo's disease patients. Med Mycol. 2011;49:643-8.

10. Bancroft JD, Stevens A, editors. Theory and practice of histological techniques. $2^{\text {nd }}$ ed. Edinburgh: Churchill Livingstone; 1982.

11. Vilani-Moreno FR, Belone AF, Soares CT, Opromolla DV. Immunohistochemical characterization of the cellular infiltrate in Jorge Lobo's disease. Rev Iberoam Micol. 2005;22:44-9.

12. Pecher SA, Croce J, Ferri RG. Study of humoral and cellular immunity in lobomycosis. Allergol Immunopath (Madr). 1979;7:439-44

13. Baruzzi RG, Lacaz CS, Souza FA. História natural da doença de Jorge Lobo. Ocorrência entre os índios Caiabi (Brasil Central). Rev Inst Med Trop Sao Paulo. 1979;21:303-38.

14. Kima PE, Constant SL, Hannum L, Colmenares M, Lee KS, Haberman AM, et al. Internalization of Leishmania mexicana complex amastigotes via the $\mathrm{Fc}$ receptor is required to sustain infection in murine cutaneous leishmaniasis. J Exp Med. 2000;191:1063-8.

15. Miles SA, Conrad SM, Alves RG, Jeronimo SM, Mosser DM. A role for $\mathrm{IgG}$ immune complexes during infection with the intracellular pathogen Leishmania. J Exp Med. 2005;201:74754.

16. Wanasen N, Xin L, Soong L. Pathogenic role of B cells and antibodies in murine Leishmania amazonensis infection. Int $\mathrm{J}$ Parasitol. 2008;38:417-29.

17. Christensen SM, Dillon LA, Carvalho LP, Passos S, Novais FO, Hughitt VK, et al. Meta-transcriptome profiling of the humanLeishmania braziliensis cutaneous lesion. PLoS Negl Trop Dis. 2017;11:e005588.

18. Azevedo MC, Rosa PS, Soares CT, Fachin LR, Baptista IM, Woods WJ, et al. Analysis of immune response markers in Jorge Lobo's disease lesions suggests the occurrence of mixed $\mathrm{T}$ Helper responses with the dominance of regulatory $\mathrm{T}$ cell activity. PLoS One. 2015;10:e0145814.

19. Vilani-Moreno FR, Opromolla DV. Determinação da viabilidade do Paracoccidioides loboi em biópsias de pacientes portadores de doença de Jorge Lobo. An Bras Dermatol. 1997;72:433-7

20. Vilani-Moreno FR, Mozer E, Sene AM, Ferasçoli MO, Pereira TC, Miras MG, et al. In vitro and in situ activation of the complement system by the fungus Lacazia loboi. Rev Inst Med Trop Sao Paulo 2007;49:87-101.

21. Brito AC, Quaresma JA. Lacaziosis (Jorge Lobo's disease): review and update. An Bras Dermatol. 2007;82:461-74. 